\title{
Analysis of the Effectiveness of Architectural Creative Learning Methods
}

\author{
Happy Indira Dewi ${ }^{1}$, Muhammad Hayun ${ }^{2}$, Ahmad Susanto ${ }^{2}$, Zulfitria Zulfitria ${ }^{1}$ \\ ${ }^{1}$ Magister Teknologi Pendidikan Universitas Muhammadiyah, Jakarta, Indonesia \\ ${ }^{2}$ Pendidikan Guru Sekolah Dasar Universitas Muhammadiyah, Jakarta, Indonesia
}

\begin{abstract}
This research is a preliminary study of the Creative Learning Model for Visual Art Gifted Children. This study aims to determine which creative learning methods are the most effective for learning architectural design. This study used observation to observe students' ability when using this method in learning, then to analyze the effectiveness level of each method used Repeated Measures ANOVA. The results of this study show that the design method with computer-based mass studies is superior to that of biodrawing, mass studies (without computers), mind maps, and biodrawing. However, based on qualitative observations, if this method is used to design at an early stage it will result in a design that is stiff and less beautiful.
\end{abstract}

Keywords - Architecture, Creative Learning Methods, Learning Methods, Technology Education.

\section{Introduction}

The application of a creative economy strategy by developing creative industries is the strategy chosen by Indonesia to face the free market at the ASEAN level and the world. The creative industry has $16 \mathrm{sub}-$ sectors that will continue to grow during 2015 2019, namely, performing arts, fine arts, television and

DOI: $10.18421 /$ TEM103-24

https://doi.org/10.18421/TEM103-24

Corresponding author: Happy Indira Dewi, Magister Teknologi Pendidikan Universitas

Muhammadiyah Jakarta, Jakarta, Indonesia.

Email: happyvisualart@gmail.com

Received: 04 December 2020.

Revised: 01 June 2021.

Accepted: 07 June 2021.

Published: 27 August 2021.

(c) BY-NC-ND (C) 2021 Happy Indira Dewi et al; published by UIKTEN. This work is licensed under the Creative Commons Attribution-NonCommercial-NoDerivs 4.0 License.

The article is published with Open Access at www.temjournal.com radio, game applications, interior design, visual communication design, advertising, music, publishing, photography, product design, fashion, film. Animation \&video, craft, culinary, and architecture.

The development of education and skills in the field of architecture in this research is the main focus. At present it is no secret that the flow of foreign workers, especially from China, has begun to dominate the labor market share, and there is even an income gap between foreign workers and local workers. To anticipate this condition, it is necessary to improve the quality of learning with qualified learning strategies. The component learning strategy is the learning sequence, method, media, and time. The learning component that is closely related to improving learning methods for desig6n is the learning method. Learning methods are concerned with using the human brain in solving design problems.

Universities as one of the educational institutions contribute to human resources in the field of architecture, it is very urgent (urgent) to have creative and reliable learning methods in the learning process. However, until now in the world of architecture, the development of learning methods that were considered sophisticated was still limited to the sophistication of media, for example learning the use of computers and the latest and sophisticated software in the field of architectural design drawing. In fact, computers and software are media and tools for architectural design. The real main tool is man himself, along with his skills and abilities, to solve design problems in the world of architecture. The abilities that are needed are, the ability to think (mindset), and the skills of students to learn and construct their knowledge and solve architectural design problems creatively and innovatively. To solve this learning problem, a reliable creative method is needed to be able to improve the quality of the way of thinking and how to learn to design for the prospective architect.

In creative learning, teachers play a role in motivating and bringing out students' creativity during learning, using various methods and strategies [1]. Various methods and strategies are used in the 
concept of using Architectural Creative Thinking, the construct is by collaborating the three concepts, namely, Creative Thinking, namely convergent divergent thinking at each stage of the Lie Tjun Tjie Transformation Process, and using the Streamlining Creative Thinking Method to visualize the process. The concept of architectural creative thinking is formed from the transformatic concept of Lie Tjun Tjie, namely the thought process to produce new findings, in practice the thought process from incubation to illumination is unpredictable and controlled, this process helps run the imagination and guides students to carry out transformation slowly. Each stage uses the work of the divergent convergent brain and utilizes methods of facilitating creative thinking. The Collaboration of Lie Tjun Tjie's Transformatic Process (A), How the Creative Thinking Brain Works (B) and Methods for Accelerating Creative Thinking (biodrawing, mass studies and mind maps) (C) produces Architectural Creative Thinking Concepts as the basis for architectural creative learning strategies [2].

The learning strategy contains four definitions, namely the sequence of activities, methods, media and time to achieve learning objectives [3]. Instructional strategies synergize the sequence of activities, methods, media and time by implementing creative thinking processes. His study specifically discusses the $\mathrm{N}$ method as a part of the components of the learning strategy. In the concept of architectural creative thinking, there are methods to facilitate creative thinking, namely by biodrawing, mass studies and mind maps.

Biodrawing stance to stimulate the visual brain and one of the right media to express imagination, with drawing activities can help the development of the human brain [4]. Biodrawing functions are: 1) To stimulate children to sharpen their visual brains; 2) Sharpening image intelligence not only makes children creative, but also good at coping with stress; 3) Train motor skills in expressing emotions and imagination; 4) Developing the ability to communicate through pictures; 5) Developing visual language skills; 6) Presenting a pleasant atmosphere; 7) Cultivate the child's right brain to be more creative; 8) Improve photographic memory; 9) Free the child to draw anything and think a whole brain; 10) Improve problem simplification skills; 11) Strengthens the detection power of something implied.

Mass study model mockups in 3-dimensional form support and foster students' skills to be more creative in design activities, which in turn can increase the effectiveness of learning, better student assignments, and better student graduation [5]. The model (mockup) as a three-dimensional teaching material is an imitation of real objects to bridge the various difficulties encountered, the original nuances of these objects can still be felt by students, without reducing the original structure, so that learning is more meaningful [6]. The types of models (mock-ups) can be grouped into 6 (six) categories, namely Solid Models, Cross-sectional Models, Stacked Models, Work Models, Mock-ups, and Dioramas.

Mind map is a way to place information into the brain and retrieve information from / outside the brain. Mind maps record creatively, effectively, and map thoughts Mind maps use color, have a natural structure that radiates from the center using curved lines, symbols, words, and images that fit into a series of simple, basic, natural rules in a way the work of the brain and turning long information into colorful diagrams is very organized, easy to remember and can work naturally [7].

Design is synonymous with design in an architectural context, it is merely a basic proposal that changes something that already exists for the better, design can be considered as a process consisting of an initial state, a transformation process and an imagined future state [8]. Philosophically, the architectural world in designing buildings and sites is related to three criteria, namely function, structure and aesthetics.

The ability to communicate with graphics, namely in developing the design process uses communication tools such as books for sketches, design sketches, models and sketch analysis. The final product is a final image, a photo of the models and the resulting report [9].

A designer's views on his role in society and the function and motivation for his work determine his understanding of the processes he uses. The designer is the party who helps the assignor to realize his dream / imagination [9].

Creative methods for learning to design are needed to help prospective architects learn to easily solve design problems. However, it is necessary to know how the method is effective so that it can be used efficiently and appropriately. Therefore, this research aims to determine which creative method is the most effective and the categorization of its effectiveness level (between Creative Methods and Biodrawing, Mass Studies, Internet-Based Mass Studies, and Mind Maps). By knowing the level of effectiveness of these creative methods, it is expected that the configuration of the use of multi-methods is appropriate to produce innovative learning strategies for learning methods, which can produce reliable architect candidates. It is hoped that human resources in the architectural sector will be able to compete, and in the future architectural works in Indonesia will be dominated by the work of Indonesian architects. 


\section{Methodology}

This research was conducted at the Department of Architecture UMJ, on 51 students who take advanced in architectural design lessons. The data collection technique uses observation, to observe student behavior when designing by using the biodrawing method; the mass study method; Computer Based Mass Study; and the mind map method. And uses a questionnaire to analyze effectiveness. The creative methods will be compared with each other: Biodrawing with Mass Study, Biodrawing with Computer Based Mass Study, Mass Study with Computer Based mass study, Biodrawing with Mind Map, Computer Based mass study with Mind Map, and Mass Study with Mind Map. Then analyzed the effectiveness level of each method used Repeated Measures ANOVA.

\section{Results and Discussion}

Biodrawing method, using brain power and hands with written media to express ideas. Even if someone is not good at drawing and not good at computers, what and how the idea of the brain is the most important. The downside of this method is that it takes a long time to change (Figure 1).

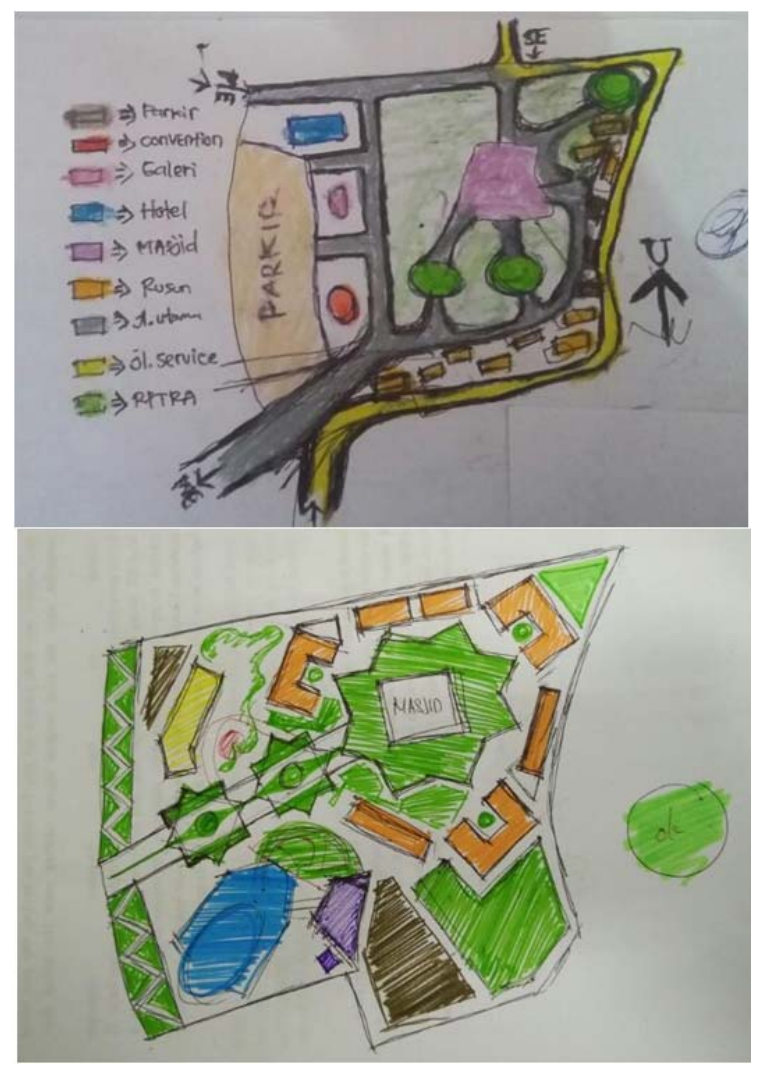

Figure 1. The use of the biodrawing method is used to produce block plan idea sketch

The mind map method in design is used to find the form of several examples of existing building forms or still in the form of sketch ideas. Several buildings are laid out around white paper. On the white paper, a new form will be produced from studying the facades or building skins that become the reference for the examples around it (Figure 2).

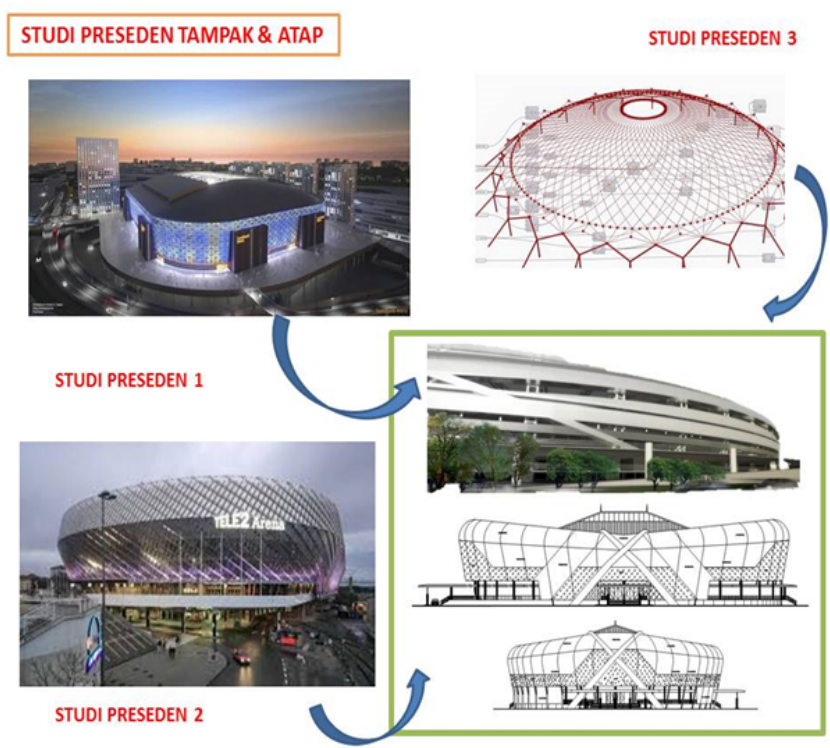

Figure 2. The mind map method in design is used to find the form of several examples of existing building forms

The mass study method is used to find the idea of placing the mass of the building that best fits the shape of the site. Various ideas for the location of the mass of the building when undergoing changes can be done quickly. The drawback of this method is the accuracy of the measurement (Figure 3).
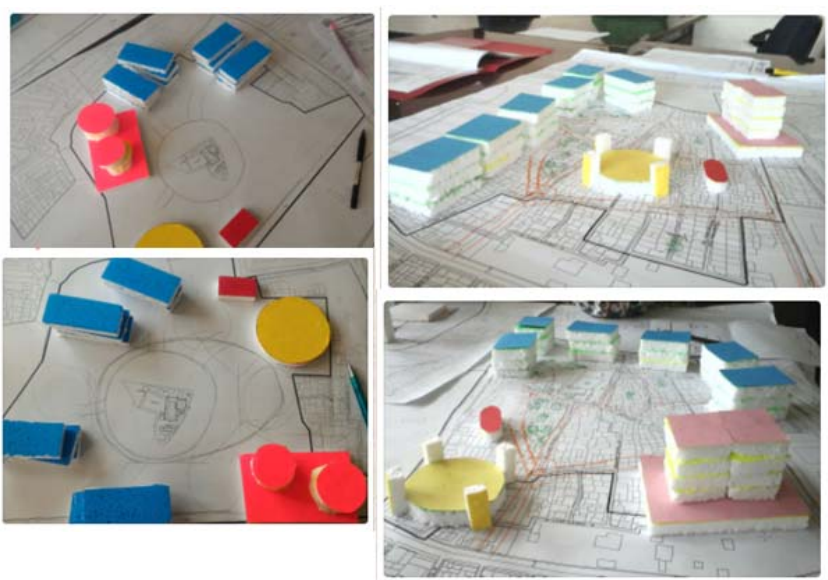

Figure 3. The mass study method is used to get an idea of the mass structure of the building in the site

Computer-assisted mass study method, using shapes that are planned and made in 3 dimensions. This method is very useful to create the ideas of the mass on the building site. The advantages of this method are about the accuracy and the convenience. It already has the basis for making pre-designed drawings. The ideas that result from this method will result in a rigid design. The use of this method requires special expertise in computer use (Figure 4). 


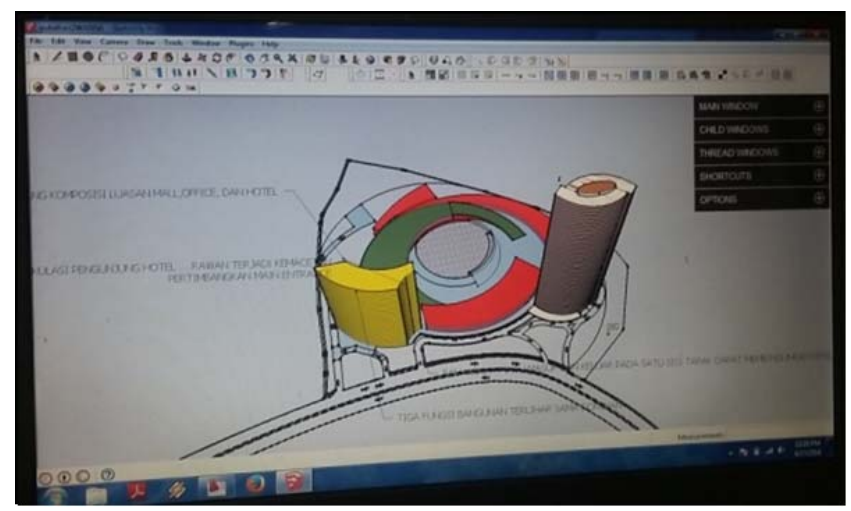

Figure 4. The computer aided mass study method was used to get an idea of the mass structure of the building in the site

After the statistical test is carried out, a description of the data is obtained which aims to describe the condition or state of the data obtained from the distribution of data to respondents, both in the form of descriptive statistical values and the condition of the respondents themselves.

The data description aims to describe the condition or state of the data obtained from the distribution of data to respondents, both in the form of descriptive statistical values and the condition of the respondents themselves.

Based on the results of the distribution of the instrument to the respondents, which amounted to 51, it was obtained descriptive statistical values for each method, namely the biodrawing method, the value of Mean 16.02, std Deviation 2.96, then the mean mass study of 12.73, std. Deviation 3.28, the study of laptop mass mean 16.33 and std deviation 2.72 and mind mapping mean 13.96 , std 3.48 , this can be seen in the Table 1 below:

Table 1. Descriptive Statistics

\begin{tabular}{|c|c|c|c|c|c|c|c|c|}
\hline \multicolumn{9}{|c|}{ Table Descriptive Statistics } \\
\hline & \multirow[b]{2}{*}{$\mathrm{N}$} & \multirow[b]{2}{*}{ 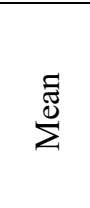 } & \multirow[b]{2}{*}{ 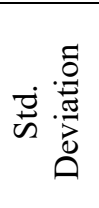 } & \multirow[b]{2}{*}{$\Xi$} & \multirow[b]{2}{*}{$\sum^{\stackrel{x}{z}}$} & \multicolumn{3}{|c|}{ Percentiles } \\
\hline & & & & & & 売 & 홀 & $\stackrel{F}{\circ}$ \\
\hline Biodrawing & 51 & 16,02 & 2,963 & 8 & 20 & 14 & 16 & 18 \\
\hline Studi_Massa & 51 & 12,73 & 3,281 & 7 & 20 & 10 & 13 & 14 \\
\hline $\begin{array}{l}\text { studi_Massa_ } \\
\text { Laptop }\end{array}$ & 51 & 16,33 & 2,725 & 8 & 20 & 15 & 16 & 19 \\
\hline $\begin{array}{l}\text { Mind } \\
\text { Mapping }\end{array}$ & 51 & 13,96 & 3,487 & 4 & 20 & 13 & 14 & 16 \\
\hline
\end{tabular}

The hypothesis was tested by using the nonparametric statistical technique test of Friedman type Chi-Square with a value of 51.49 and a Sig. 000 $<0.05$, then there are significant differences in the effectiveness of creative methods in learning architecture. Below is a comparison between one method with each other:

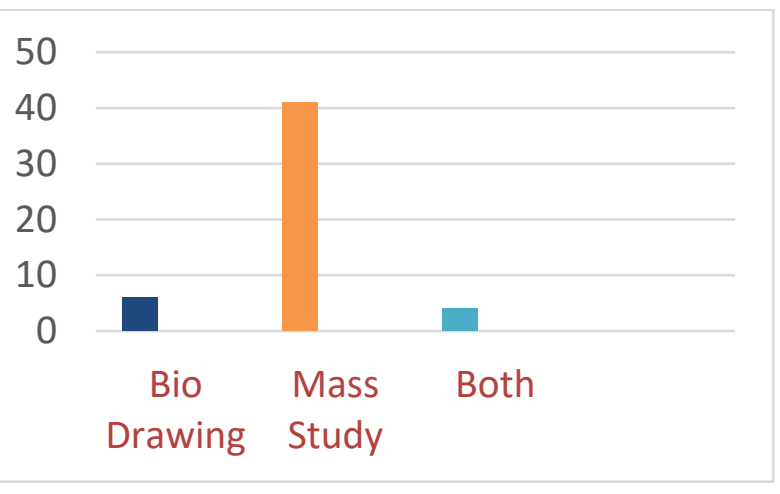

Figure 5. Comparison Biodrawing - Mass Study

From Figure 5 it is found that 6 students chose to use the biodrawing method in design learning and 41 students chose to use the mass study method in learning architecture.

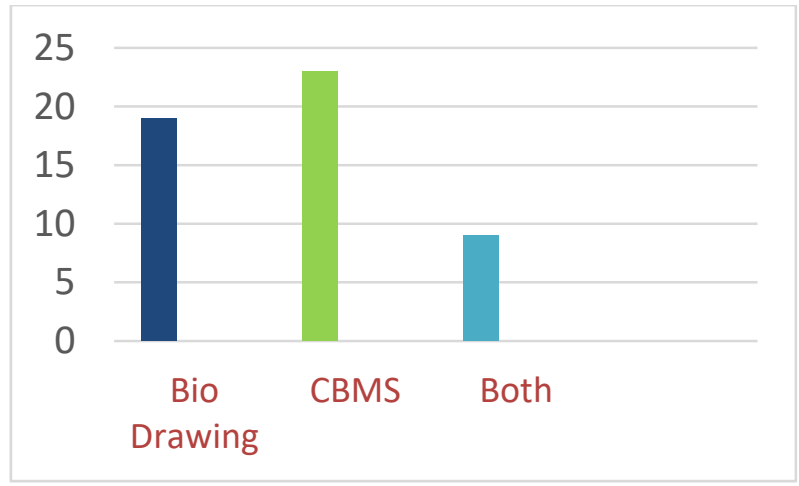

Figure 6. Comparison Biodrawing - Computer Based Mass Study

From Figure 6 it is found that 19 students chose to use biodrawing in design learning and 23 students chose to use the laptop mass study method in learning architecture and 9 people chose both.

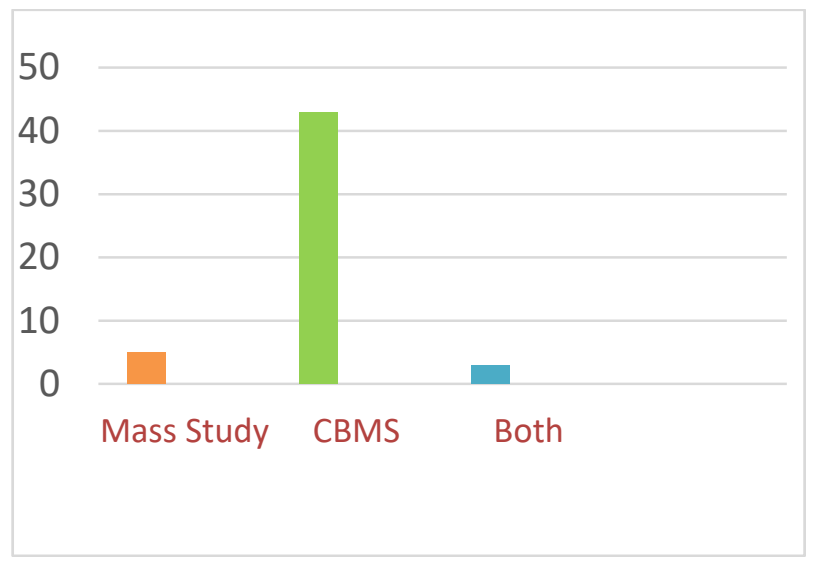

Figure 7. Comparison Mass Study - Computer Based Mass Study

From Figure 7 it is found that 5 students chose to use mass studies in architectural design learning and 43 students chose to use the laptop mass study method in learning and 3 people chose both. 


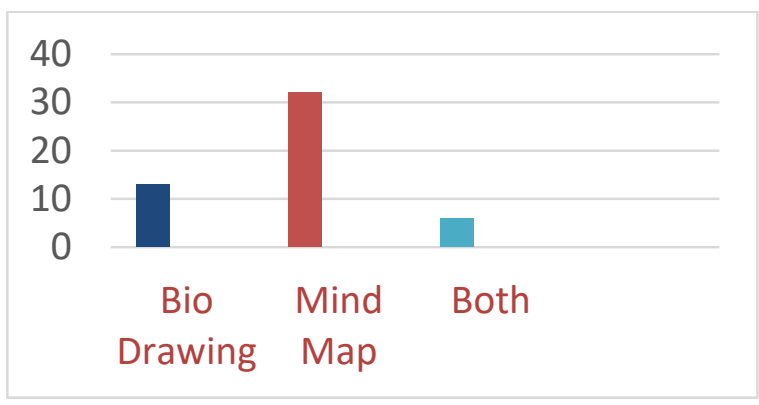

Figure 8. Comparison Biodrawing - Mind Map

From Figure 8 it is found that 13 students chose to use biodrawing in design learning and 32 students chose to use the laptop mass study method in learning and 6 people chose both.

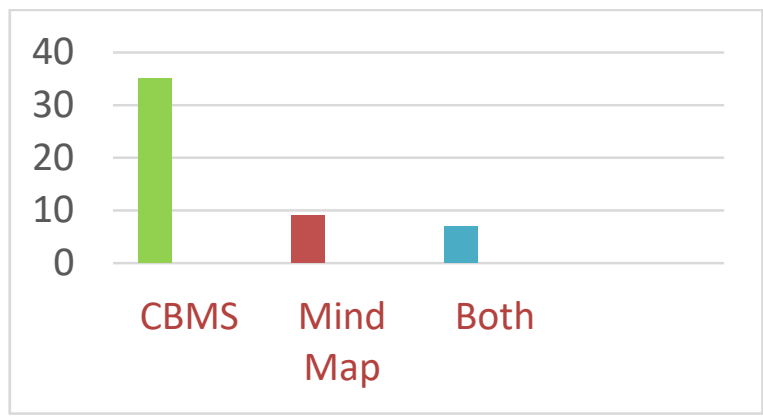

Figure 9. Comparison Computer Based mass studyMind Map

From Figure 9 it is found that 35 students chose to use the laptop mass study in learning architectural design and 9 students chose to use the mind map method in learning and 7 people chose both.

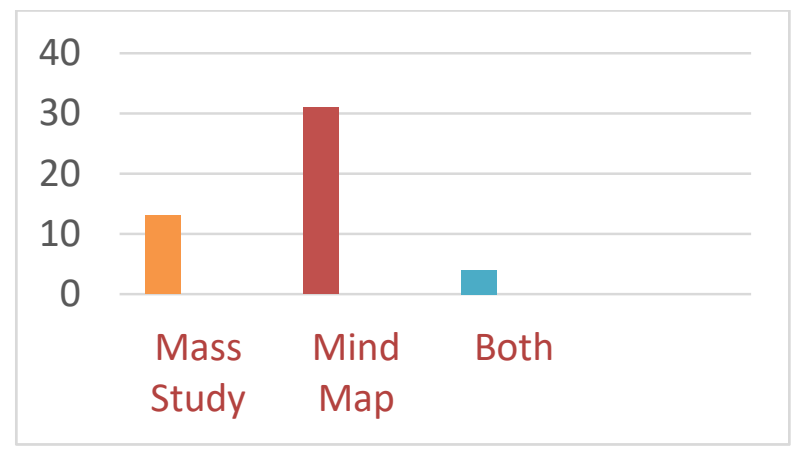

Figure 10. Comparison Mass Study - Computer Based Mass Study

From Figure 10 it is found that 13 students chose to use mass studies in learning architectural design and 31 students chose to use the mind map method in learning and 7 people chose both.

\section{Conclusion}

From the results of statistical tests, it is known that the design method with computer-based mass studies is very superior to other methods (biodrawing, mass studies, and mind maps). However, based on qualitative observations, if this method is used to design at an early stage it will result in a design that is stiff and less beautiful.

Therefore, a mix method is needed in making the design. The first design idea uses biodrawing, then in the next stage using a mind map to get ideas from existing designs. Furthermore, mass order using a manual mass study is followed by using a computerbased mass study.

\section{Acknowledgements}

This research is preliminary research from research on Creative Learning Models For Visual Art Talented Children which was carried out in 2018 to 2020, funded by ministry of Research and Technology/ National Research and Innovation Agency of The Republic of Indonesia based on Decree SK Dirjen Strengthening Risbang Number 3/E/KPT/ 2018 January 3 and Agreement/ Contract with University of Muhammadiyah Jakarta Number: 81.SPK/LPPM-UMJ/V/2018.

\section{References}

[1]. Uno, Hamzah B. dan Nurdin Mohamad. (2012). Belajar dengan Pendekatan Pembelajaran Aktif Inovatif Kreatif Effektif Menarik. Jakarta: Bumi Aksara.

[2]. Dewi, H. I. (2015). Pengembangan Strategi Pembelajaran Berlandaskan Cara Berpikir Kreatif untuk Membuat Karya Arsitektur. JTP-Jurnal Teknologi Pendidikan, 17(2), 107-118.

[3]. Suparman, A. (2004). Pendidikan jarak jauh: Teori dan praktek. Pusat Penerbitan, Universitas Terbuka.

[4]. Olivia, F. (2010). Meroketkan Kekuatan Otak Kanan Dengan Jurus Biodrawing. Elex Media Komputindo.

[5]. Azmi, M. Fathien. (2007). Metode Pembelajaran Yang Tepat Untuk Mata Kuliah Berbasis Studio Pada Jurusan Arsitektur :Pengembangan Proses Pembelajaran Interaktif Pemanfaatan Media Maket Model Pada Studio Perancangan Arsitektur Pada Student Centre Learning. Prosiding Semiloka Nasional Pendidikan Arsitektur, Jakarta, Indonesia.

[6]. Prastowo, A. (2011). Panduan Kreatif Membuat Bahan Ajar Inovatif. Jogjakarta:DIVA Press.

[7]. Buzon, Toni. (2010). Buku Pintar Mind Map. Jakarta, Indonesia: Gramedia.

[8]. Snyder, James C. dan Anthony J. Catanese. (1989). Pengantar Arsitektur. Jakarta: Penerbit Erlangga.

[9]. Atmadi, Parmono, Sidharta, Suwondo Bismo Sutedjo dan Eko Budihardjo. (1997). Perkembangan Arsitektur dan Pendidikan Arsitek di Indonesia. Yogyakarta, Indonesia : Gajah Mada University Press. 